\title{
GIS-Based Factorial Ecology and Social Public Space of the Twin City of Ramallah and Al-Bireh, West Bank, The Palestinian Authority
}

\author{
Sireen Al-Shawamreh1, Yahya Farhan ${ }^{2 *}$ \\ ${ }^{1}$ Department of Geography, University of Jordan, Amman, Jordan \\ ${ }^{2}$ Member of the Trustee Council of Al-Ahliyya University, Amman, Jordan \\ Email: *wjetfan47962@gmail.com
}

How to cite this paper: Al-Shawamreh, S. and Farhan, Y. (2018) GIS-Based Factorial Ecology and Social Public Space of the Twin City of Ramallah and Al-Bireh, West Bank, The Palestinian Authority. Journal of Geographic Information System, 10, 261-282. https://doi.org/10.4236/jgis.2018.103014

Received: May 16, 2018

Accepted: June 18, 2018

Published: June 21, 2018

Copyright ( $) 2018$ by authors and Scientific Research Publishing Inc. This work is licensed under the Creative Commons Attribution International License (CC BY 4.0).

http://creativecommons.org/licenses/by/4.0/

\begin{abstract}
In the present research, a factorial ecological approach using factor analysis was employed to evaluate the dimensionality of the urban social structure of the twin city: Ramallah and Al-Bireh, West Bank, the Palestinian Authority. Through factor analysis, the 41 variables were reduced to four factors with an eigenvalue $>1.0$. These factors explain 77.07 percent of the total variables used in the study. Factor I contributes $28.419 \%$ of the total variance proportion of input variables, labeled as "family, housing, and public spaces factor". Factor II accounts for $19.57 \%$ of the variance proportion, designated as" housing and urban public spaces". Factor III is strongly correlated with variables referring to the characteristics of the head of the family, and the availability of public spaces, and thus, is designated as "head of the family and public spaces". It explains $16.68 \%$ of the total variance. Finally, factor IV explains $12.406 \%$ of variance proportion, and is strongly associated with variables pertaining to a lack of public social spaces. Consequently, factor IV is termed "lack of public spaces". The spatial distribution of factor scores related to factors I to IV was mapped using Arc GIS in order to analyze the spatial patterns of the recognized four factors. It is worth noting the factor IV, which refers to the lack of urban social space and, urban public space, which persists in the twin city, and will continue to persist in the future. The lack of urban open space and public social spaces is closely connected to migration, emerged housing pattern, and family status dimensions focused on factors I to III, continuous confiscation of the Palestinian lands, and the construction of Israeli settlements. Currently, the twin city is extremely overcrowded with stone/concrete buildings at the expense of public space which has declined continuously over the last three decades. Nevertheless, the analyzed spatial pattern of factor scores indicated the homogeneous character of the urban society of the twin city. Based on
\end{abstract}


the urban ecological models which seek to characterize the Western, non-Western, Israeli, and Arab-oil producing (e.g., Kuwait) urban structures, it is difficult to elaborate a specific Palestinian urban ecological model with reference to the models developed elsewhere.

\section{Keywords}

Urban Structure, Public Spaces, Factor Analysis, Family Status, Housing Pattern, Twin City

\section{Introduction}

The development of a wide variety of socio-economic characteristics of urban areas has been a central and very important theme of research since the 1960's. Thus, the urban ecology of residential areas has been investigated by geographers, economists, sociologists, city planners, political scientists, and human ecologists [1]. The recognition of a limited number of dimensions operating throughout an urban area enables testing of the hypothesis of social differentiation, and allows for similar and dissimilar urban areas to be clarified and demarcated. The resultant information is meant to be useful as a basis for decision-making processes. Factorial ecological studies have dealt with a wide range of Western cities (i.e., in North America), other such urban areas (in Britain, Canada, Australia, New Zealand), non-Western cities (such as Calcutta), Arab cities (urban areas in oil-producing countries such as Kuwait), other Arab cities: Cairo (Egypt), Jerash (Jordan), and the twin city (within the Palestinian Authority). Comparative factorial ecology [2] has been carried out on different cities elsewhere. For example, Evans [3] studied three towns in South Wales, while Timms [4], and Johnston [5] had investigated the same four towns in New Zealand. Further, Murdie [6] analyzed the factorial ecology of metropolitan Toronto, 1951-1961, while Davies and Barrow [7] compared the factorial ecology dimensions in three Canadian cities. A comparative factorial ecological study was carried out between a US city (Jacksonville, Florida), and a non-western agglomeration, the city of Kuwait [8], The application of factor analysis techniques to the study of social-structuring of urban areas has been given the general designation "factorial ecology" [9] [10].

Conventional "factorial ecology" comprises the application of factor analysis to data describing the residential differentiation of the population generally in the urban population [11]. The major source of data in this context is the various national censuses for large or metropolitan cities. Alternatively, comprehensive socio-economic surveys were carried for factorial ecological studies on small third world cities and towns, such as in Jordan [12], and the current study on the twin city of Ramallah and Al-Bireh. The major dimensions in such studies on Western cities are: social rank and status, family life cycle, ethnicity [13], residential structure and patterns [14], residential segregation in metropolitan areas 
[15], social status, urbanization, ethnicity, and what recently has been termed "hyper-segregation" [16] [17] [18] [19], or so called “ethno-burbs" [20] [21], which are characteristic dimensions of the US metropolitan areas. Furthermore, studies related to third-world cities revealed prominent deviations from predominant Western model. Abu-Lughod [22], Berry and Rees [23], Hossain [24], Al-Ankary [8], and Farhan and Tarazi [12], for example, identified different dimensions in urban Cairo, Calcutta, Kuwait, and Jerash (Jordan). These are: 1) socioeconomic status, 2) male dominance and 3) social disorganization for Cairo; a) land use gradient, (b) social statues, c) core-suburb duality in activity, d) houseless population, e) household industry, and f) transport district for Calcutta. Al-Ankary also revealed five dimensions connected to Kuwait City as an example of cities that developed early on an oil-producing Gulf state. These dimensions are: 1) low socio-economic status, 2) high socio-economic status, 3) Palestinians and Jordanians, 4) middle-status foreign population, and 5) low-status foreign population [8]. He also noted that in Kuwait City, segregation is ethnographic [8], such as the concentration of unskilled Asian laborers in certain areas, and socio-economic, where Kuwaitis' are residents of especially designated areas for them and closed for non Kuwaiti's. Moreover, there are also certain areas occupied by foreigners (higher-status population, and low-status immigrants (manual workers)). This pattern of segregation seems to be emphasized by local factors rather than being a general factor of the region [8]. Conversely, in a study dealing with the factorial ecology of Haifa as "planned", "command", and "controlled" economic and political systems, Gradus [1] recognized four dimensions: a) socio-economic status, b) ethnicity, c) Arab minority dimension, and d) density and land use gradient. However, Taylor and Parks [25] argued that conventional factorial ecology informed us about the characteristic of the population of the city as they appear in the "middle of the night". Thus, they sought to add to the factorial ecology approach the daytime activities of the population, and they experimented with the concept of space and time in factorial ecology using the same procedures of analysis. In the recent past, Grove [26], and Grove and Burch [27] elaborated a social-ecological approach to identify the dimensions of ecosystem, i.e., the application of social ecology to urban ecosystem and landscape analysis. Supplementary to socio-economic data, special analysis of social differentiation was carried out based on hydromorphic differentiating characteristics (i.e., topographic, soils, hydrological, and nutrient parameters), and biotic differentiating characteristics (i.e., extent and structure of vegetation, species composition, and distribution parameters). They applied an urban ecosystem framework and landscape approach in Baltimore, Maryland. Excessive urban and suburban development has become a major factor in environmental degradation of cities. Rapid urbanization, affects radically land use/land cover, biodiversity, habitat structure, loss of species and hydro-systems locally and regionally. Recently, urban ecological research based on integrating natural and social sciences is advancing to establish the 'science of cities' as a 
new topic of research. Urban nature conservation, open space planning, protection of ecosystem services, management of control measures, and the conflict between humans and nature [28] [29] [30] [31] are main issues in urban ecology. In the current study, urban dynamics, led to the transformation of housing pattern, from large single-family housing to largely apartments housing, compounded by lack of public spaces, consequently, several variables were added to the questionnaire to assess the need of residents for open urban and spaces to practice their social activities. In the present study, the principal axis or common factor analysis has been used and performed upon the data. A varimax orthogonal rotation was then employed to simplify the structure and aid in the interpretation of the factors. The socio-economic dimensions of the twin city were identified and the spatial distributions of factor scores were established as prevailing in 2016. The results may provide useful information for social and city planners. Irrespective of the fact that the twin city is small in terms of population size (the total is about 85,000 ), it has been largely influenced by rural urban migration, and accommodates immigrants from the Gaza Strip, other Palestinian governorates and Palestinian immigrants who have migrated back from the Gulf and other Arab states, Europe, and North America to their homeland of Palestine.

Since the twin city Ramallah and Al-Bireh hosts most of the governmental institutions, recreational facilities, and jobs, it has become a preferential focus for the residential choice for the Palestinians. The impact of urban dynamics on changing housing patterns from large single-family dwellings to apartments increases the demand for housing and has sparked a dramatic rise in land prices given the myriad obstacles imposed by the Israeli occupation to limit urban expansion. Therefore, an extraordinary need for public spaces is evident, and therefore the quality of life is continuously deteriorated. The twin city accordingly, is unique as a blockaded urban area by the Israeli occupation. The advantage of a factorial ecology approach is that it permits a large number of variables to be included in the analysis, and the technique can be employed to identify the prevailing dimensions which reflect the internal structure of the twin city. The data matrix containing a large number of variables can be reduced to a smaller number of factors.

\section{Methodology}

\subsection{Data Source}

Due to the lack of official detailed census data pertaining to the Palestinian cities in the West Bank, the present authors designed a compressive questionnaire which includes 41 variables and covers the whole population of the twin-city of Ramallah and Al-Bireh (Figure 1), comprising a total of 84,029 residents in 82 officially demarcated areas. The population of the twin-city is distributed between Ramallah (58\%) and Al-Bireh (42\% of the total). A map of scale 1:28,000 acquired from the Ministry of Local Government [32] displays the 82 areas (the observation units). According to this map, the twin-city is divided into 82 areas 
or observation units. Each is considered by the Palestinian Central Census Department [33] as a "population concentration". The 82 areas represent the observation units with defined boundaries and are utilized for census and research purposes (Figure 2). Each area has an official recognized name (Table 1). A

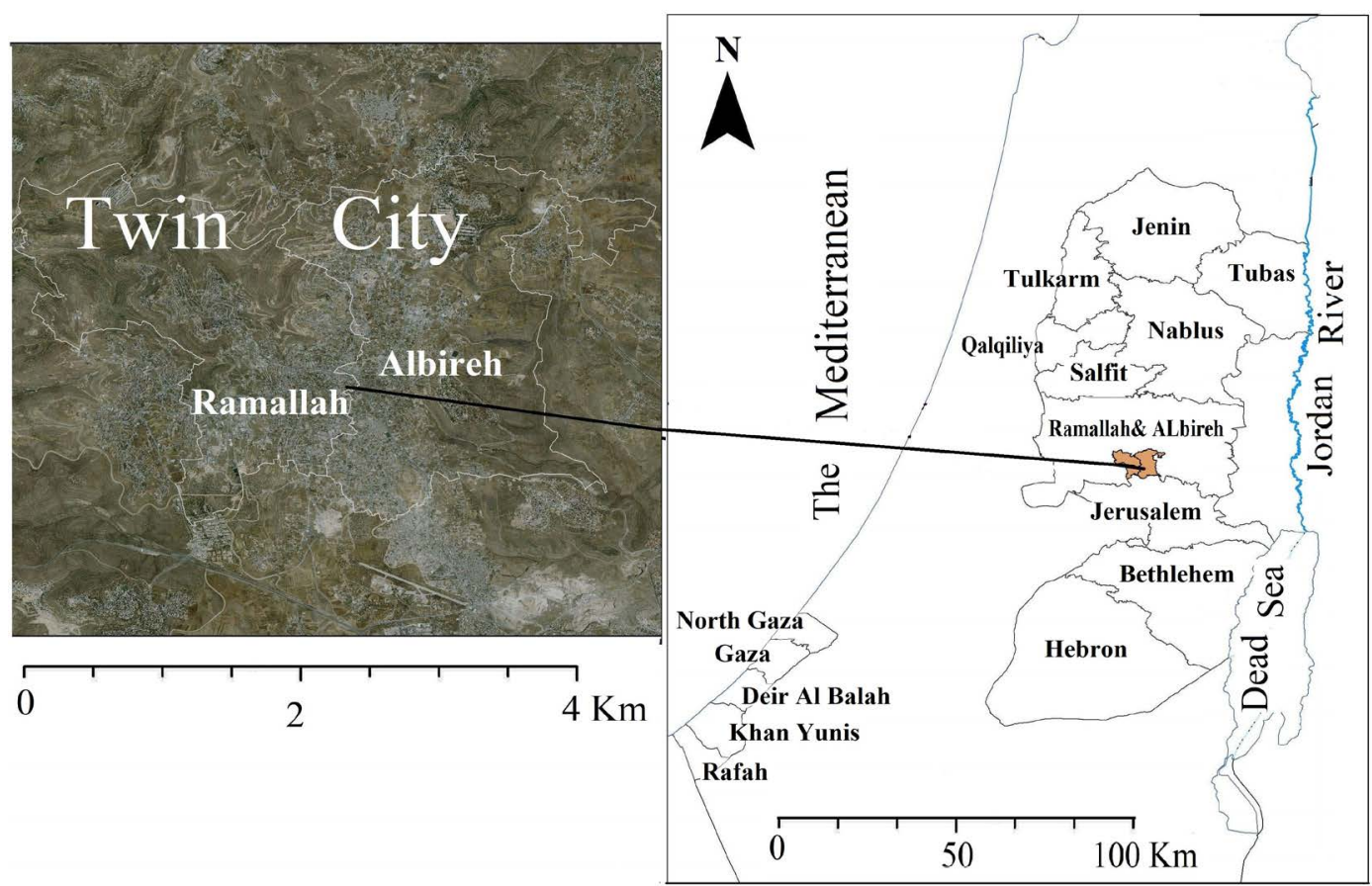

Source: Google Earth Bro, $1^{\text {st }}$ January 2017.

Figure 1. Location of the Twin City: Ramallah and Al-Bireh, and image of the Twin City.

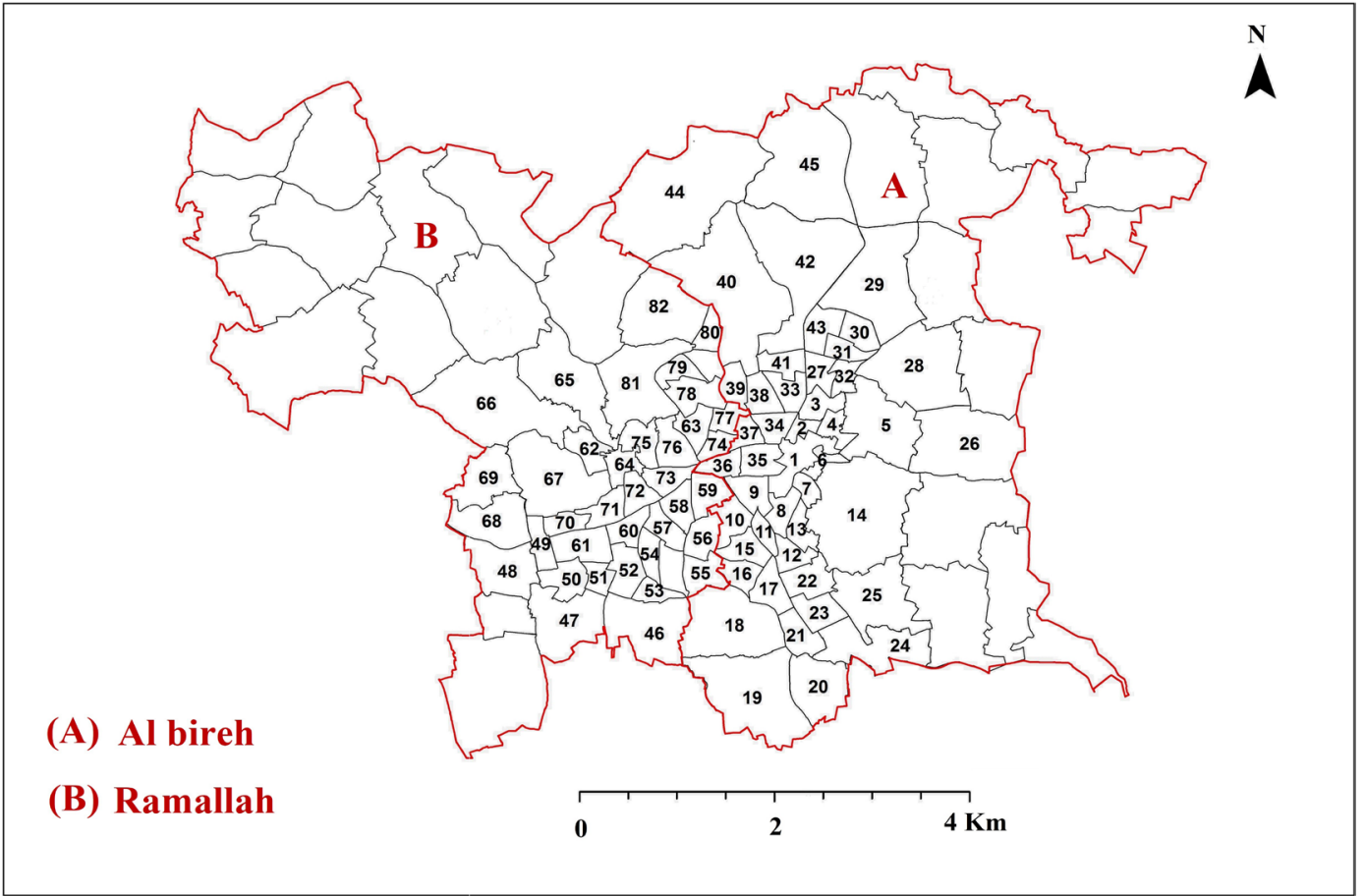

Figure 2. The 82 areas of Ramallah and Al-bireh (Source [32]). 
Table 1. Names of the 82 areas.

\begin{tabular}{|c|c|c|c|}
\hline Number & Area & Number & Area \\
\hline 1 & Old City-AlBireh & 42 & Albalou' \\
\hline 2 & Albaladiya & 43 & Beer Alras \\
\hline 3 & Khalet Em Ali & 44 & Alslameya \\
\hline 4 & Ars Alkhar & 45 & Hayi ksab \\
\hline 5 & Khalet El Amya & 46 & Almasiun \\
\hline 6 & Karm Jaser & 47 & Khalet Altaeima \\
\hline 7 & Al homa & 48 & Al sharqee Alshamali \\
\hline 8 & Al bos & 49 & Alsinseiu \\
\hline 9 & Al medan & 50 & Almuryjima \\
\hline 10 & Ras Hussein & 51 & Hayi Alshaqreh \\
\hline 11 & Alsharfeh & 52 & Aaen mnjed \\
\hline 12 & Alashb al ahmer & 53 & Dar yosef \\
\hline 13 & $\mathrm{Al}$ dwareh & 54 & Dar Awad \\
\hline 14 & Jabl Altaweel & 55 & Alnhdeh \\
\hline 15 & Al basboos & 56 & Bor Saeed \\
\hline 16 & Al mbarekh & 57 & Alhuseen \\
\hline 17 & Al baqie & 58 & Alnozha \\
\hline 18 & Um Alsharayet & 59 & Mokhayem Qadoreh \\
\hline 19 & Khalet alquran & 60 & Alnser \\
\hline 20 & Tel Alnasba & 61 & Jamal Abed Alnaser \\
\hline 21 & Altal & 62 & Ibrahim \\
\hline 22 & Al shieh alshamali & 63 & Al'amireh Alyeh \\
\hline 23 & Alshieh Aljanubi & 64 & Old City-Ramallah \\
\hline 24 & Sateh Marhaba & 65 & Aljadwal \\
\hline 25 & Alsbaheya & 66 & Altereh \\
\hline 26 & Sheban & 67 & Batn Alhawa \\
\hline 27 & Qiteat Sheban & 68 & Aljanobi Alsharqi \\
\hline 28 & Qartees Alkharbi & 69 & Alshamali Alsharqi \\
\hline 29 & Almesqat & 70 & Dar Zoghb \\
\hline 30 & Alqbarseh & 71 & Alqustel \\
\hline 31 & Aljour Altahta & 72 & Mar jeryes \\
\hline 32 & Hariqt Harb & 73 & Almughtaribin \\
\hline 33 & Sahel Awad & 74 & Alfnadeq \\
\hline 34 & Ras Altahuneh & 75 & Alqadirh \\
\hline 35 & Aleurqan & 76 & ghassan \\
\hline 36 & Almnareh & 77 & Almsayef \\
\hline 37 & Sabiha & 78 & Alkrmel \\
\hline 38 & Algharbia & 79 & Aljbel \\
\hline 39 & Almarkaz & 80 & Dar Juries \\
\hline 40 & Alethaeh & 81 & Ayen Alkrzm \\
\hline 41 & Aljur Alfawqa & 82 & Rdana \\
\hline
\end{tabular}


comprehensive survey was conducted during the period extending from April to December 2016. The raw data matrix comprises 41 variables representing a range of dimensions: socio-economic, demographic, educational, housing, the need for urban social spaces, religion, migration (internal and from abroad), and occupation (Table 2). All variables are expressed in percentages. The questionnaire covers $98 \%$ of the urban residents or families resident in the twin-city. Due to the dynamic changes in the city, and the impact of such changes on housing patterns, a prominent lack of public spaces for the residents to practice their seasonal, weekly or, daily activities exists. Therefore, the questionnaire includes 13 variables covering the urban social spaces which the residents (the children included) require to engage in the daily activities in their lifeworlds.

\subsection{Statistical analysis}

The data matrix $(41 \times 82)$ was subjected to factor analysis, where the varimax rotation procedure was employed using SPSS software (v. 20). Factor analysis as a data reduction technique, reduces attribute space from a large number of variables to a smaller number of factors (or components), which are then correlated with the 41 chosen variables. The method of factor analysis consists of several steps: 1) calculate the Pearson's product-moment correlation coefficient (PPMCC) matrix to reveal the highly loaded variables on each factor, and how much the variability in the original variables is explained by each factor; 2) extract the initial factors, and determine how many factors, to use in the final solutions; 3 ) rotate the original variable space so as to maximize the variance of the resultant factors. Eigen-values have been used to determine how many factors to use in the final solution; all factors with an Eigen-value $>1.0$ are considered in the analysis. All factors explaining less than five percent of the overall variance should be excluded, because any factor explaining less than this proportion must likely include a large proportion of random-error variance. The marked break of discontinuity in slope of the scree plot divides the more significant factors the less significant ones. In this regard, the four-factor solution is considered the best choice [8]. The normalized varimax rotation was employed and used to compute factor loadings between the original variables and the final factors [34]. Although different methods were elaborated to calculate factor scores in SPSS, factor scores are generated by multiplying "factor (or) component score coefficient matrix" with standardized original variables [35]. The identification and interpreting of the factors is based on loading of the variables on the factors. The process simply measures the correlation between the variables and the factors. The higher the loadings, the stronger the correlation. A classification of factor loadings was suggested in order to refer to the strength of the relationship between the variables and the extracted factors. When factor loading is $>0.9$, the relationship is categorized as very strong. Similarly, loadings ranging from $>0.8$ to $<0.9$ are described as a strong relationship. When loadings are $>0.7$, but $<0.8$, the relationship is considered moderate. Finally, loading values $<0.7$, are classified 
Table 2. Variables included in the study.

\begin{tabular}{|c|c|c|}
\hline No. & Variable term & Description of variable \\
\hline 1 & Ycam & Year moved to the twin-city \\
\hline 2 & Hfam & Head of the family \\
\hline 3 & Afam & Age \\
\hline 4 & Rfam & Religion \\
\hline 5 & $\mathrm{Pbf}$ & Place of birth (town/city) \\
\hline 6 & PbfG & Place of birth (governorate) \\
\hline 7 & PPOR & Previous place of residence of the family head \\
\hline 8 & PPORG & Previous place of residence (governorate) \\
\hline 9 & FSS & Social status of the family head \\
\hline 10 & JSW & Job status of the family head (working) \\
\hline 11 & Wphf & Working place of head of the family \\
\hline 12 & Dawe & Does anybody else work in the family \\
\hline 13 & TMI & Total monthly income (in Jordanian Dinars) \\
\hline 14 & HS & Housing style (Single-family house/apartment) \\
\hline 15 & WMCR & When moved to current residence \\
\hline 16 & HA & Area of the resident place $\left(\mathrm{m}^{2}\right)$ \\
\hline 17 & NR & Number of rooms \\
\hline 18 & $\mathrm{H} / \mathrm{AO}$ & House/apartment ownership \\
\hline 19 & PRIC & Price of house/apartment \\
\hline 20 & HWC & How the house was chosen when buying or renting \\
\hline 21 & Rchc & Reason for choosing the resident location \\
\hline 22 & Gard & Availability of community gardens \\
\hline 23 & GREN & Availability of green spaces/parks \\
\hline 24 & Club & Availability of sports facilities \\
\hline 25 & Plibr & Availability of public library \\
\hline 26 & Cofsh & Availability of coffee shops \\
\hline 27 & Malls & Availability of malls \\
\hline 28 & Wedding & Availability of wedding halls \\
\hline 29 & Chilp & Availability of places for children's daily activities. \\
\hline 30 & TREL & Type of relationship with the residents of the apartment/house \\
\hline 31 & Rell & Relationship is limited to the people of the building where they live \\
\hline 32 & Pwed & Availability of places for wedding activities \\
\hline 33 & PRAM & Availability of places for Ramadan gathering \\
\hline 34 & $\mathrm{PHCO}$ & Availability of places/houses of consolation \\
\hline 35 & PFAM & Availability of places for family meeting \\
\hline 36 & PEid & Availability of places for Eid meeting \\
\hline 37 & DMov & Do you plan to move to another city \\
\hline 38 & Mov & Movement to another place in the city \\
\hline 39 & AMov & Aim of moving to a place \\
\hline 40 & Occup & Occupation of the head of the family \\
\hline 41 & Edus & Education of the head of the family \\
\hline
\end{tabular}


as a relatively weak correlation. Consequently, the factor loading provides means of examining the patterns of interaction that exist within urban society. The next matrix derived by manipulating the factor matrix is called the factor score matrix. Factor scores represent the scores of each observation unit (area or census tract) on each factor. Factor scores are derived by weighting each variable proportionally to its involvement in a factor. Thus, the more involved a variable, the higher the weight. Variables not closely connected to a factor would be weighted near zero. To determine the score for an observation unit on a factor, the observation unit data on each variable is multiplied by the factor weight for each variable. The sum of these results gives the factor score for each observation unit [8] [12] [36] [37]. This weighted summation will provide the observation unit high (or low) score if their values are high (or low) on the variable involved in the factor. Factor scores furnish a means to identify the spatial dimension of urban sub-areas as defined with reference to those basic patterns of interaction. The factor scores associated with the main dimensions representing the extracted factors are mapped for the observation units of the twin-city using Arc GIS tools. Thus maps which display the spatial pattern of each factor based on the computed factor scores were compiled.

\section{Results and Discussion}

\subsection{Factor Dimensions}

Factor analysis resulted in four major factors (Table 3). It can be seen that these factors whose eigen-values are greater than one, together account, for $77.077 \%$ of the total variance explained by the 41 variables. Table 4 displays eigen-values, variance proportion, and cumulative variance proportion. It is obvious that the first factor contributes $28.419 \%$ of the total variance proportion of input variables, whereas, factors II-IV account for $48.7 \%$ of the total variance. Furthermore, the most effective variables in factors I-IV are shown in Table 2. It is clear that among the variables those with the greatest proportion of variance are the following: the head of the family (Hfam), religion (Rfam), the number of rooms in the house, or apartment (NR), the house/apartment ownership (H/AO), how the resident place was chosen when buying or renting (HWC), the type of relationship with residents of apartment/houses (TREL), the reasons for choosing the resident location (Rchc), the availability of a public library (Plibr), the availability of wedding halls (Pwed), the availability of places for Eid gathering/greetings ( $P$ Eid), and the occupation of the head of the family (Occup). They also exert the greatest effect on the first factor the factor loadings revealed that factor I describes variables related to the family characteristics, housing, and the availability of urban public spaces. Consequently factor I is labeled as the "family, housing, and public spaces" factor. It is worth noting that the 13 variables representing the need for public spaces existing in the four major factors, and most of them exhibit very strong, strong, or moderate correlation with the identified factors. Exerting the greatest effect on factor II (Table 2), 
Table 3. Varimax rotated factor matrix and loadings.

\begin{tabular}{|c|c|}
\hline Loading & Variable title and number \\
\hline Factor I & Family, housing and public spaces ( $28.42 \%$ of the total variance) \\
\hline 0.966 & $(\mathrm{Hfam}) 2$ \\
\hline 0.979 & $(\mathrm{Rfam}) 4$ \\
\hline 0.500 & $(\mathrm{PbfG}) 6$ \\
\hline 0.901 & (NR) 17 \\
\hline 0.820 & $(\mathrm{H} / \mathrm{AO}) 18$ \\
\hline 0.969 & (HWC) 20 \\
\hline 0.891 & (RChc) 21 \\
\hline 0.644 & (Plibr) 25 \\
\hline 0.601 & (TREL) 30 \\
\hline 0.965 & $(\mathrm{PHCO}) 32$ \\
\hline 0.953 & (PEid) 36 \\
\hline 0.962 & (Occup) 40 \\
\hline Factor II & Housing and urban public spaces ( $19.57 \%$ of the total variance) \\
\hline 0.659 & (DAWE) 12 \\
\hline 0.952 & (HS) 14 \\
\hline 0.968 & (HA) 16 \\
\hline 0.896 & (Gard) 22 \\
\hline 0.976 & (Club) 24 \\
\hline 0.982 & (Chilp) 29 \\
\hline 0.954 & $(\mathrm{DMOV}) 39$ \\
\hline Factor III & Head of the family and public spaces ( $16.68 \%$ of the total variance) \\
\hline 0.688 & (A fam) 3 \\
\hline 0.647 & $(\mathrm{Pbf}) 5$ \\
\hline 0.639 & (Fss) 9 \\
\hline 0.692 & $(J S W) 10$ \\
\hline 0.650 & (WMCR) 15 \\
\hline 0.795 & $(\mathrm{GREN}) 23$ \\
\hline 0.695 & (MAII) 27 \\
\hline 0.743 & (P Ram) 33 \\
\hline Factor IV & Lack of urban public spaces ( $12.406 \%$ of the total variance) \\
\hline 0.901 & $(\mathrm{P}$ poR $) 7$ \\
\hline 0.618 & (Plibr) 25 \\
\hline 0.836 & (Cofsh) 26 \\
\hline 0.844 & (Wedd) 28 \\
\hline 0.784 & (P Fam) 35 \\
\hline
\end{tabular}


Table 4. Total variance explained by factors.

\begin{tabular}{cccccccccc}
\hline \multirow{2}{*}{ Component } & \multicolumn{3}{c}{ Initial Eigenvalues } & \multicolumn{3}{c}{ Extraction Sums of Squared Loadings } & \multicolumn{3}{c}{ Rotation Sums of Squared Loadings } \\
\cline { 2 - 9 } & Total & \% of Variance & Cumulative \% & Total & \% of Variance & Cumulative \% & Total & \% of Variance Cumulative \% \\
\hline 1 & 20.980 & 51.170 & 51.170 & 20.980 & 51.170 & 51.170 & 11.652 & 28.419 & 28.419 \\
2 & 6.217 & 15.162 & 66.332 & 6.217 & 15.162 & 66.332 & 8.025 & 19.572 & 47.991 \\
3 & 3.423 & 8.348 & 74.680 & 3.423 & 8.348 & 74.680 & 6.839 & 16.680 & 64.671 \\
4 & 2.064 & 5.035 & 79.715 & 2.064 & 5.035 & 79.715 & 5.086 & 12.406 & 77.077 \\
5 & 1.446 & 3.526 & 83.241 & 1.446 & & & & & \\
6
\end{tabular}

which comprises $19.572 \%$ of variance proportions, are the following variables: if anybody else works in the family (DAwe), housing style (single-family house, or apartment) (HS), the area of the resident place $\left(\mathrm{m}^{2}\right)(\mathrm{HA})$, the availability of community gardens (Gard), the availability of sports/recreational facilities (Club), obtainable places for children's daily activities (Chilp), and the aim of moving to live to the twin-city (AMOV). Again, the second factor reflects variables which represent housing characteristics, and the need for public spaces in the observation units or areas. Thus, it is appropriate to label the second factor as "housing and urban public spaces". Factor III is strongly associated with the following variables (Table 3): age of the head of the family (Afam), the place of birth (Pbf), social status of the head of the family (Fss), job status of the family head (JSW), when the family moved to the current residence (WMCR), the availability of green spaces/parks (GREN), the availability of malls (MALL), obtainable places for Ramadan gathering in the future (Pram), and the last variable; why are you thinking to move to another town or city (Mov). It is obvious that factor III represents variables related to the characteristics of the head of the family, and urban public spaces, and it contributes $16.68 \%$ of the total variance. Therefore, this factor has been termed the "head of the family and public spaces". Variables such as previous place of residence (PPOR), the presence of public library (Plibr), the availability of coffee shops (Cofsh), wedding halls (Wedd), and places for other social activities (PSOC) have the greatest impact on factor IV (Table 3), and contribute $12.406 \%$ of variance proportions. Again these variables are highly loaded on factors referring to the lack of public social spaces in the twin-city of Ramallah and Al-Bireh. Thus, the fourth factor reflects the "lack of social public spaces". It can be concluded that the identified factorial dimensions of the twin-city demonstrate a pronounced deviation from those recognized in the Western and third world cities including the Arab city structures as illustrated earlier.

Instead, it is evident that the general pattern emerges in the twin-city as a result of urban dynamics and its impact on housing patterns change. The dimension representing the "lack of urban open public space and social space" persists and will continue to be significant in the future within the twin city. Such di- 
mension is also closely connected with housing pattern and family status dimensions. Socio-economic stratification, ethnic status, religious status, and segregation which characterize the urban residential structure of American, European, Canadian, and Israeli cities are not recognized here. If can therefore be claimed, that the recognized four factors indicate the predominance of a relatively homogenous urban-residential structure between the 82 areas of the twin-city. However, noticeable variation in housing style/pattern is observed between different groups of families which settled in the city in different time periods since the peace process began in 1990s, or even before. If we consider the loadings $>0.4$ and $<0.6$ in the analysis, and in labeling of factors, the family status, housing patterns, and urban social public space dimensions will intermix to create more or less a single factor that accommodates family characteristics variables, housing pattern, and social public space variables. The dominance of urban social public space as a dimension in all factors makes it an important dimension in the twin-city. At present, most of the city families are living in apartments (71.9\% of the total), with a remarkable lack of social public spaces to engage in their activities, including likewise the children. Social public space, particularly parks, and community gardens provide critical ecosystem services. Green space, also supports "physical activities, psychological well-being, and the general public health of urban residents". Thus, environmental justice in the city is crucial, and green space in developed urban areas often accessed for residents of all neighborhoods [38] [39] [40].

\subsection{The Factor Patterns}

\subsubsection{Factor I: Factor Scores}

The spatial distribution of factor scores for factor I show relatively six distinct patterns. Low negative factor scores (Figure 3) represent three scattered patterns and accommodate observation units distributed in the north, south, east, west and central parts of the twin city. The $(-0.1-<0.0)$ pattern reflects areas of high population density such as area no. 1 around the C.B.D of Al-Bireh City, a refugee camp established in 1948 in the central part following the Israeli occupation of Palestine, and area no. 40 is located in the northwestern part of Al-Bireh. This area is considered a new suburb which was established following the creation of the Palestinian National Authority. As a result of excessive migration, the demand for houses has increased rapidly; thus, a large number of houses were constructed where a new suburb emerged, such as area no. 40. Areas with negative scores are homogenous in terms of family characteristics (i.e., head of the family, religion, place of birth, and occupation). Here, the husband is the head of the family and in a few cases where the husband has died; the oldest son is the head of the family, such as in the old city of Al-Bireh. The dominant religion is Islam, and most residents were born in the twin city, with a small fraction born in the occupied territories of 1948 that comprise the State of Israel. They live in Qadoura camp (area no. 59) on the border between Ramallah and Al-Bireh. Various occupations were observed among them, i.e., governmental Jobs, primary 


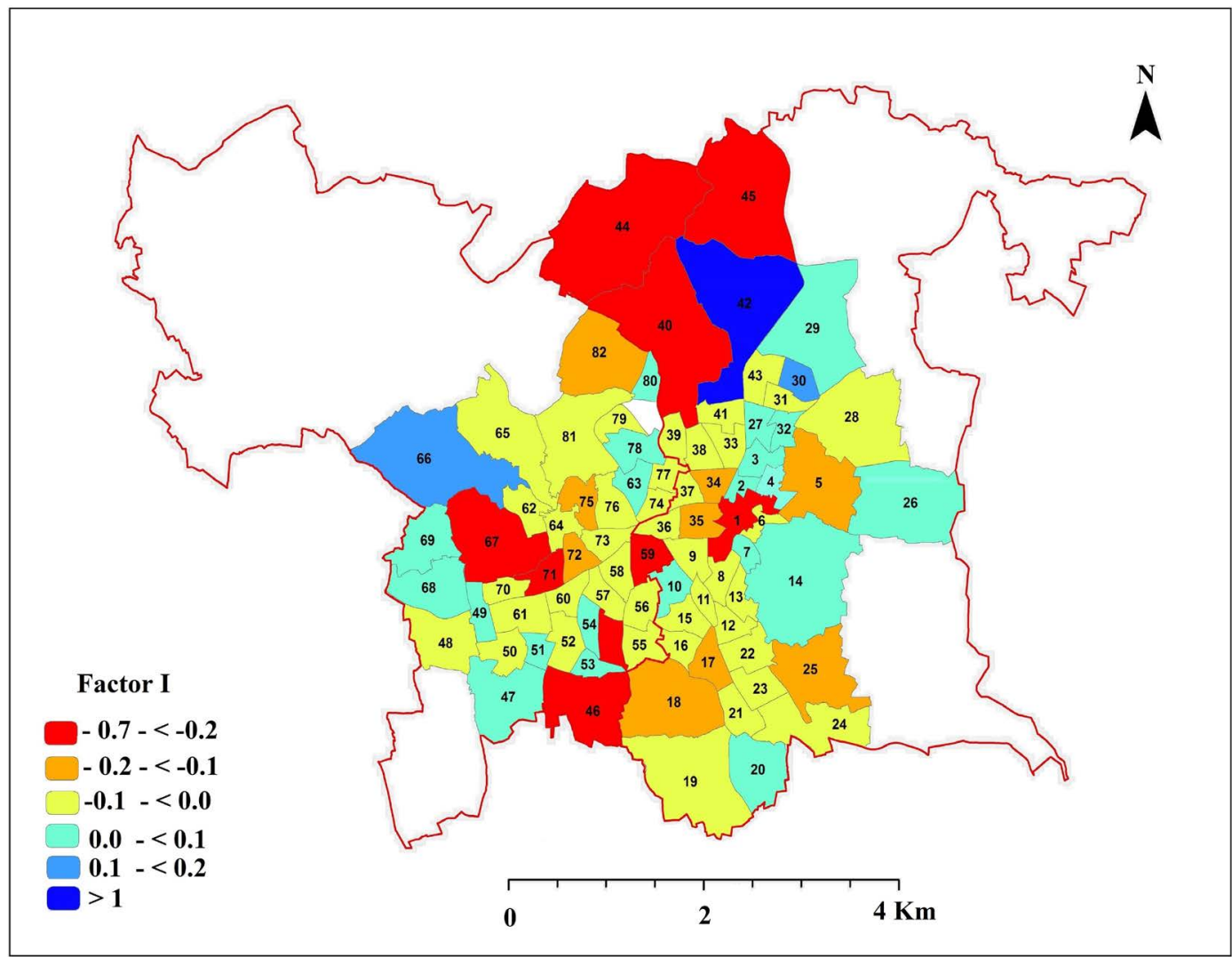

Figure 3. Factor scores for factor I.

occupations including skilled and unskilled labor, and employment in education.

Housing characteristics comprise: number of rooms, house/apartment ownership, why the house was chosen when buying or renting and the reason for choosing the resident location). The survey revealed that houses are owned by the residents, and the house is normally chosen by the family or friends. Most of the families do not socialize with other families in the building, and families live in houses constructed on the original father's house (second, or third floor, etc.). Generally, the number of rooms available in each housing unit is three unless the family lives in a single family house, or in a large building of several stories. In this case the house includes more than three rooms. Such a pattern of housing is dominant in areas located in the old core section of Al-Bireh city. Further, there is a striking lack of public spaces, i.e., libraries, places of consolation, spaces for family meetings, and places for eid meeting/gathering. Most of the families pursue these activities in special places called "Dawawin", or in their large single-family houses, such as are located in central and old neighborhoods of Al-Bireh.

The second negative scores pattern $(-0.2-<0.1)$ includes nine areas in the north, center, and southern part of the twin city. These areas are characterized by large population, and evince the same family status as observed in the previous pattern. Again, the families here own their housing units, and a small number of families in the central and southern part rent their houses and apartments. The same characteristics of public spaces were reported by the residents. 
The third negative scores pattern $(-0.1-<0.0)$ dominates the largest number of areas in the twin city, especially in its central and southern parts.

The total population number is varied (large [1000 - 800], moderate [700 500] and small [400-less than 400]) in these areas, and most of the families are Muslim, along with a few Christian families living in the old city of Ramallah. A large proportion of manpower is employed working for the government, in education, sales, handcrafts, services, and primary jobs. Here few families rent their houses, and the lack of public spaces for social activities is quite notable.

Factor scores for factor I also exhibit three patterns of low positive scores. The total population in the three patterns varies from large to relatively small numbers. However, a small total population dominates the northern and central parts of the twin city, whereas a large total population is found in area 42 of Al-Bireh city. The people of this area are mostly immigrants who came from other governorates, and work in the governmental institutions, most of which are located in this area. Family and housing status, and the availability of public spaces in this area (no. 42) resemble relatively the same factors that characterize the areas in the previous patterns. A considerable number of families here are Palestinian immigrants who have returned from abroad, i.e., the Gulf States and the Americas. Moreover, most of the families own their housing units (especially apartments). It is worth noting that area no. 66 of the second pattern of factor scores $(0.1-<0.2)$ in Al-Bireh city, is occupied by families who have relocated from other governorates to the twin city.

\subsubsection{Factor II: Factor Scores}

Three patterns of low negative scores are observed (Figure 4). The lowest category $(-0.5-<-0.3)$ represents the southern part of Al-Bireh city, namely areas no. 18 and 19. The dependency ratio of the families there is lower than other areas. More than one working in the family including the wife; consequently, the economic status is relatively higher compared to families living in other areas. $72 \%$ of the families are living in large single-family houses they own, or in large buildings for the extended families. The remaining $30 \%$ of families are immigrants who came from abroad, or from other governorates and live in apartments with footage ranging from $100-140 \mathrm{~m}^{2}$. Most of them work for the Palestinian Authority.

The children pursue their varied activities in the parking lots of the building, or in the apartments.

The second category of negative factor scores $(-0.3-<-0.2)$ is restricted to six areas located in the southern part of the twin city (nos. 44, 67, 59 in Ramallah, and areas nos. 14, 25, and 17 in Al-Bireh). A large population lives in these areas. Along with the head of the family, other persons are also employed. $26 \%$ of these families here migrated from other governorates mainly due to the availability of employment, and they plan to stay permanently in these areas. Apartments are the dominant housing style, especially in area no. 59. Although public gardens are obtainable in area nos. $25,67,59$, and 14 , these are insufficient to 


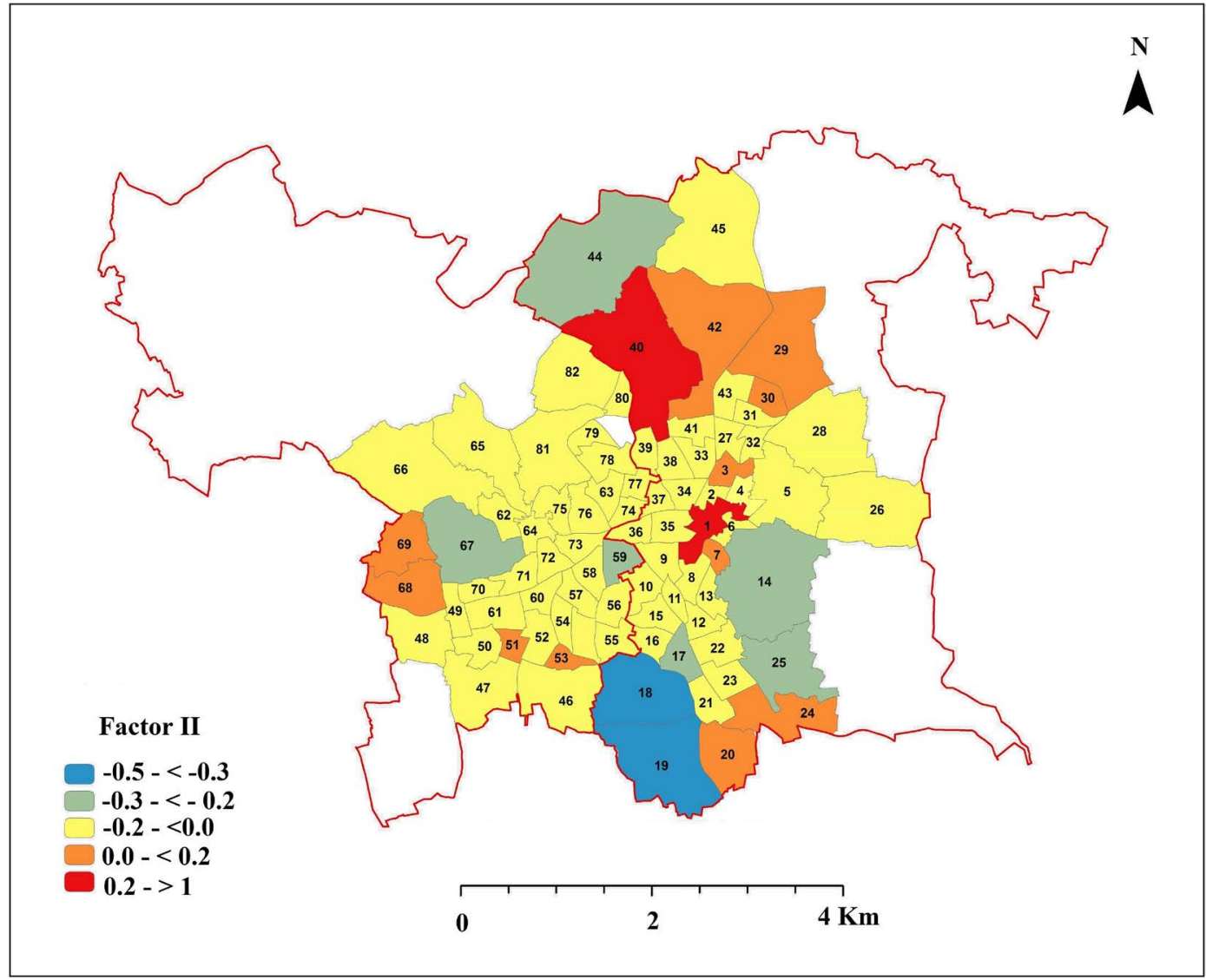

Figure 4. Factor scores for factor II.

meet the requirements of increasing population. Furthermore, sports facilities and clubs are to some extent available, but a shortage in spaces for children's daily activities is evident.

The third pattern of negative factor scores $(-0.2-<0.0)$ is dominant in 61 areas of the twin city (Figure 4 ), where a moderate total population characterizes these areas. The family economic and housing status is similar to those observed in the previous negative patterns discussed above. Single-family housing style can be observed in several areas, but the apartment housing dominates in areas such as: nos. $46,66,77$, and 82 . This is an indication of changing mode of housing more recently in the twin city. Urban public spaces are available in area nos. $5,46,52,65,66,67,81$, and 82 . By comparing the large number of areas and the associated residents, with the available urban public spaces (including spaces allocated for children's daily activities), it is obvious that these public spaces are insufficient to meet the requirements of the population and children's daily activities. The public gardens, for example, are available only in area nos. 5, 46, 47, and 82.

Two patterns of positive scores $(0.0-<-0.2$ and $0.2-<0.1)$ can be observed (Figure 5). The first pattern is found in the northern, central, and southern part of the twin city, whereas, the second pattern is restricted only to Al-Bireh city. The family and housing characteristics resemble those dominant in the previous 


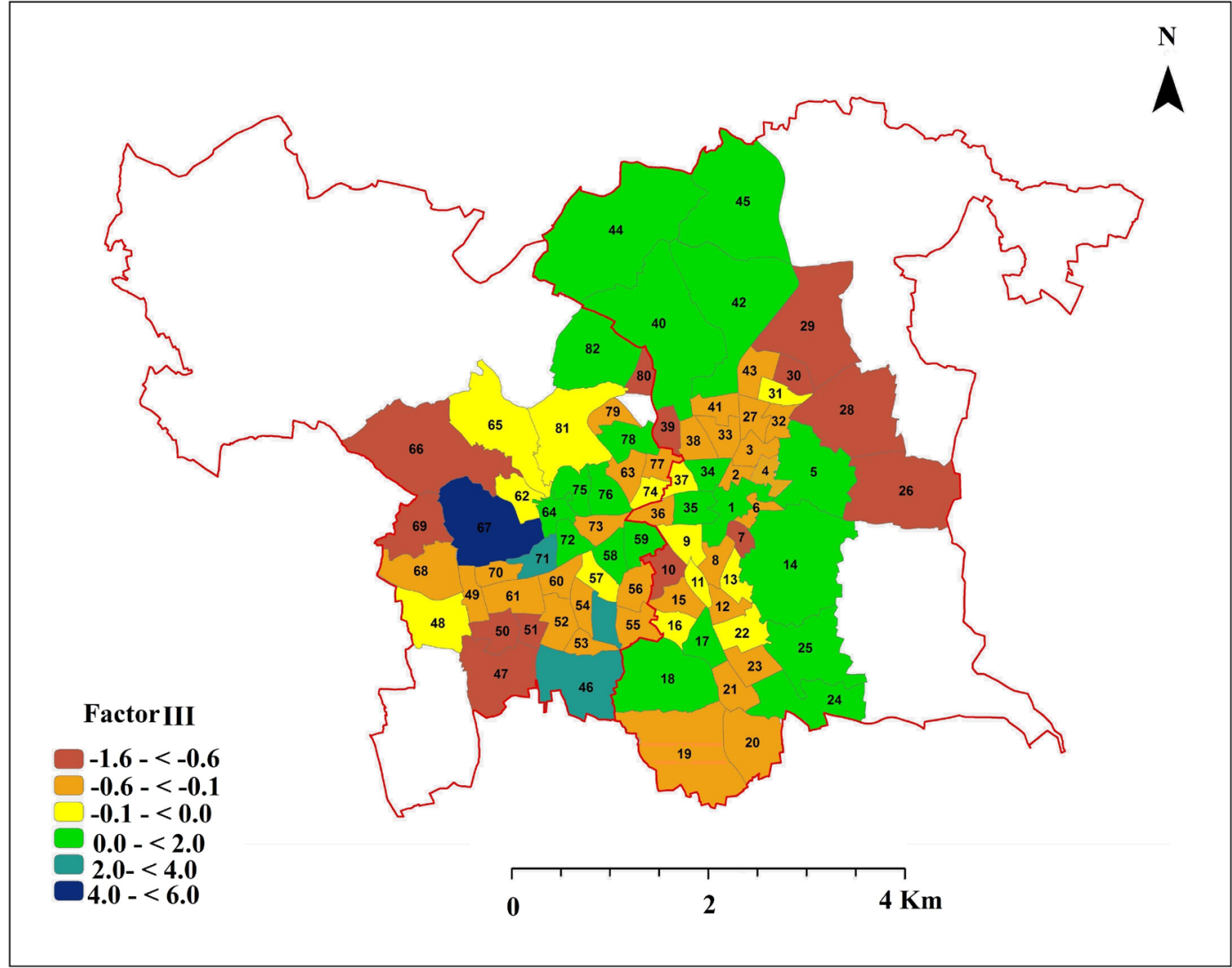

Figure 5. Factor scores for factor III.

categories of factor scores. Although, the single-family housing style predominates, apartment buildings have recently sprung up in these areas following the arrival of the Palestinian Authority. Thus, radical changes in housing style and population behavior have developed over the last 25 years. There is an identifiable notable shortage in urban public spaces. Only one garden has been created in area no. 42. The second pattern of positive factor scores is found in two areas: nos. 1 and 40 in Al-Bireh. There is little evidence of an apartment-based housing style in the old city (area no. 1) as compared with old single-family houses, while the two housing styles exist in area no. 40. However, only one open public space is available in this area.

\subsubsection{Factor III: Factor Scores}

The spatial distribution of factor scores for factor III (Figure 5) shows three negative $(-1.6-<-0.6 ;-0.6-<0.1 ;-0.1-<0.0)$ patterns, and three positive patterns $(0.0-<2.0 ; 2.0-4.0 ; 4.0-6.0)$. The total population in these areas is generally high or moderate. As far as the family status is concerned, the age of the head of families ranges from 40 to 49 years. Most of them have migrated in from other governorates of the West Bank, thus, the category of the prevalent age group, i.e., 30 to 50 years of age comprises most age groups settled in these areas, and $95.5 \%$ of the members of this age group are married. $63 \%$ of this age group were born either in the twin city, or other cities in the West Bank, or stem 
from the 1948 Palestinian refugees who were expelled from their homeland following the Israeli occupation of Palestine, or are from the Gaza Strip. Most of the families have moved to these areas less than 10 years ago due to the relative economic prosperity of the twin city acting as a migration magnet. Due to the Palestinian uprising in 2007, the Israeli army of occupation installed a large number of military barriers associated with repeated attacks by the Israeli army in these West Bank areas, a factor that pushed a large number of families to move and to settle in these specific locations. Although the predominant style of housing is of the apartment type, these areas suffer from a lack of green and open spaces due to the continuous Israeli confiscation of the Palestinian lands in Ramallah and Al-Bireh. $62.8 \%$ of the respondents to the questionnaire believe that urban open spaces are not available, whereas $24 \%$ of them claim that available green/open spaces are not adequate in such crowded areas. Further, $62.8 \%$ of the respondents reported that malls are not available, while $24 \%$ of the respondents considered the present malls insufficient in number to meet the requirements of the residents in these areas. Also, around a third of the respondents pursue their social activities such as Ramadan eftar either in the Dawaween (s), or in large houses. The three categories of positive factor scores are distributed in the northern, central, and southern parts of the twin city. The total population in these areas is relatively high. The family and housing status are also similar to the families as characterized living in areas related to the categories of negative factor scores. The third category of factor scores $(4.0-<6.0)$ (Figure 5) is restricted solely to area no. 67 in Ramallah. The green/public spaces are rare in the first positive category of factor scores due to the establishment of an Israeli settlement, Psagot built on a hill in the eastern part of Al-Bireh in area no. 14, called Jabal Al Taweel (Taweel Hill). However, the vacant land which belongs to $\mathrm{Al}-\mathrm{Bireh}$ and Ramallah is rare at present due to the Israeli occupation and continuous confiscation of the Palestinian land in the twin city, especially the strategic high lands overlooking the cities and rural areas, and the fertile lands belonging to the rural Palestinians. However, following the 1967 War, and the Israelis occupation of the West Bank, three Israeli settlements were established on the Palestinian lands in the twin city. These are: Psagot settlement established on Jabal Al Taweel; Beit El, constructed on land in the northern part of the twin city; Kokhav Ya'akov, which is built on land in the southeastern part of Al-Bireh.

\subsubsection{Factor IV: Factor Scores}

As illustrated earlier, factor IV is named the "lack of urban public spaces" in the twin city. The emergence of this factor indicates a remarkable shortage of urban public spaces in the twin city generally, although some observation units are crowded with residents. Three categories of negative factor scores $(-4.0-<-0.2$; $-0.2-<-0.1$; and $-0.1-<0.0)$, and four categories of positive factor scores $(0.0$ $-<0.3 ; 0.3-<0.6$ ' $0.6-<0.8$, and $>1.0$ ) are observed in the northern, central, and southern parts of the twin city. The distribution of first category of the negative factor scores is restricted to eight areas located in the central part of the 


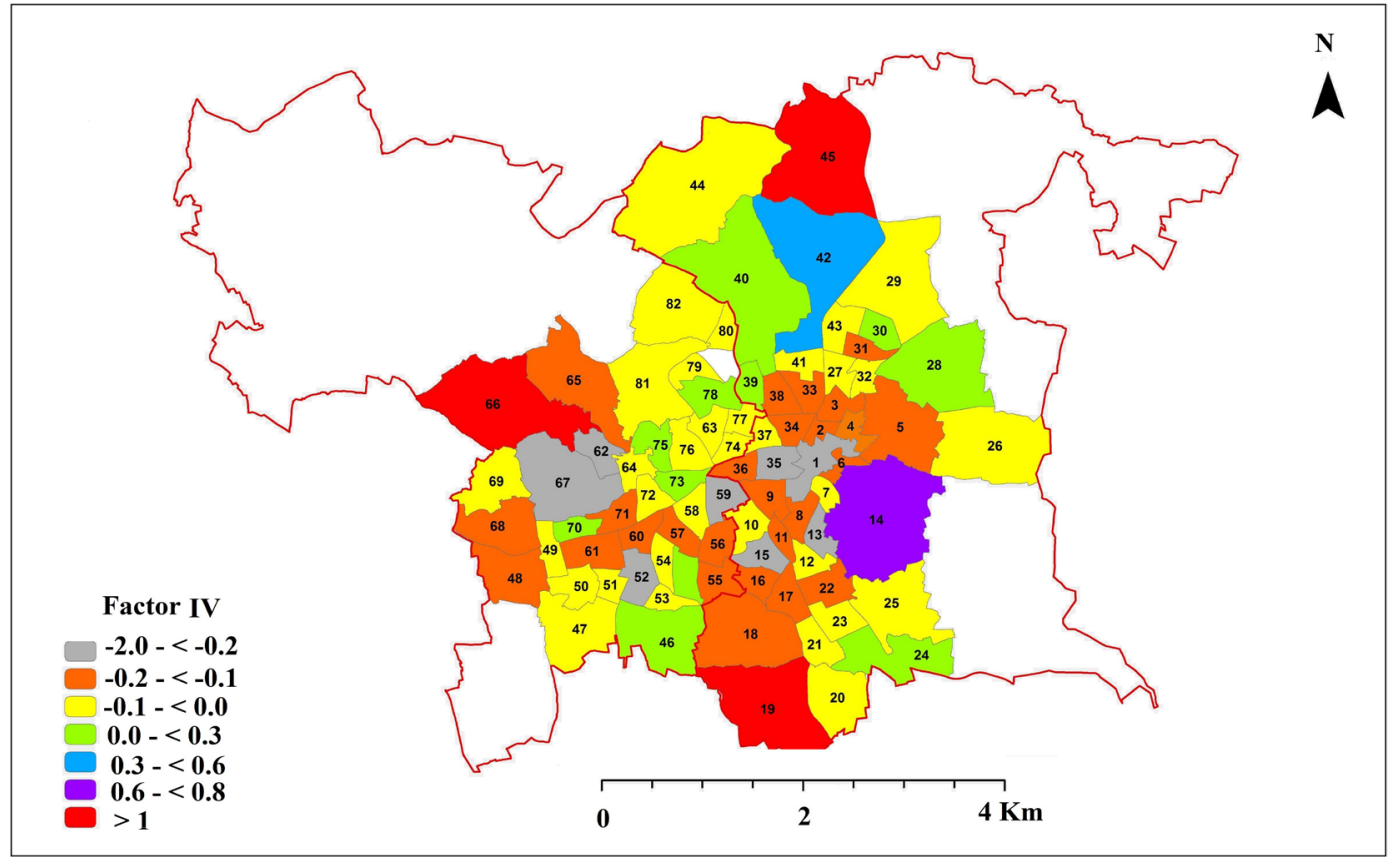

Figure 6. Factor scores for factor IV.

twin city (Figure 6). The total population of these areas varies from high to moderate. The previous living place of residents' who live in these areas was in Palestine/Israel (the 1948 refugees), or they moved from other parts of the West Bank following the 1967 War. 83\% of families pursue their social activities such as family meetings in the Dawaween(s), wedding halls, and halls connected with other cultural associations. Two-thirds of the respondents reported that although public libraries, wedding halls, and coffee shops are relatively available in these areas, they are not adequate to meet the requirements of the residents who live in these areas. The areas of the second category of negative factor scores are characterized by a lack of coffee shops, and wedding halls are available in only five areas: nos. 34, 18, 11 at Al-Bireh, and area nos. 55 and 48 in Ramallah. Public libraries are not available. However, the wedding halls available in the twin city are only in area no. 23 in Al-Bireh, and in area 49 in Ramallah. The four positive categories of factor scores are distributed in the northern, central and southern parts of the city. Although some areas are crowded (such as area no. 14, Jabal Al Taweel), public libraries are not available in all areas. Coffee shops do not existed in certain areas, and one wedding hall can be found in area no. 40 .

\section{Conclusion}

From factor analysis of the 41 variables, seven factors with an eigenvalue $>1.0$ were produced, and only four factors served to explain $77.7 \%$ of the total variables employed in the current study. The first factor contributes $28.4 \%$ of the total variance proportion of the input variables. The factor loading showed that factor I was strongly correlated with variables relating to family status, housing pattern, and the availability of urban public spaces. Thus, it is labeled the "fami- 
ly, housing, and public spaces" factor. Factors II-IV account for $48.7 \%$ of the total variance. Factor II accounts for a proportion of $19.57 \%$ of variance, and is strongly correlated with variables representing housing status, and the need for public spaces; consequently, it is labeled the "housing and urban public spaces" factor. Conversely, Factor III is strongly associated with variables pertaining to the characteristics of the head of the family, and urban public spaces, and serves to explain $16.68 \%$ of the total variance. As a consequence, this factor has been labeled "the head of the family and urban social space". Further, factor IV contributes $12.406 \%$ of variance proportion. Variables referring to the lack of public social spaces in the twin city are highly correlated with factor IV, which is termed "lack of public urban space". It is clear that the identified factorial dimensions of the twin city demonstrate a pronounced deviation from those recognized in the Western and third-world cities, including the Arab city structure as exemplified in Kuwait City. Although considerable variation exists regarding socio-economic and housing status between the 82 observation units in the twin city, socio-economic stratification, ethnic and religion status, and segregation, which characterized the urban residential structure of many American, European, Canadian, and Israeli cities are not apparent here. It can be concluded that the four factors identified and the spatial patterns of factor scores analyzed indicate the dominance of a relatively homogeneous urban-residential structure across the 82 observation units of the twin city. Nevertheless, noticeable variation in housing style has emerged (due to recent changes in housing patterns) between different groups of families who settled in the city during different time periods since the peace process (Oslo Accord) which began in 1994, or even before. If factor loadings $>0.4$ and $<0.6$ are considered in the analysis, the urban social public space dimension will intermix with other factors to create a single factor, encompassing substantial family and housing status, and public space variables. The prevalence of urban public space variables in the factorial dimensions of the twin city makes it a common element in the recognized factors. Most of the families at present are living in apartments $(71.9 \%$ of the total), with a remarkable shortage in urban public and social public spaces to pursue their activities, including children's activities. After the Palestinian National Authority (PNA) came to the Palestinian territories in 1994, a pronounced change in housing pattern occurred: from a large-single house dwelling to the predominance of apartments. This caused a dramatic rise in land' prices. Moreover, the traditional pattern of the extended family has also transformed into a smaller nuclear family type. Additionally, the population in the twin city has increased rapidly due to the return of Palestinians from abroad, and internal migration from other Palestinian governorates to this urban area, where the Israeli army established a large number of checkpoints in the occupied territories (the West Bank/Palestine) during the Al-Aqsa Intifada in 2000. The permanent military checkpoints have led to a significant cut-off of transportation/communication between the Palestinian governorates, and represent an obstacle for employees to 
access their jobs in other governorates. The disruption of free unhindered transport between the Palestinian governorates has encouraged internal migration from these governorates into the twin city, intensifying a great demand for housing. High land prices are considered a major cause of changes in housing patterns, i.e., from large single-family housing to crowded apartments. Consequently, a lack of areas allocated to public social space has emerged. This problem is exaggerated due to continuous confiscation of large areas of land by the Israeli occupation, in order to establish and expand the Israeli settlements. As a result, the expansion of the Palestinian settlements which belong to the jurisdiction of the Palestinian National Authority and twin city is highly restricted to specific areas constantly decreasing in size due to Israeli occupation and land confiscation. At present, the twin city is extremely overcrowded with stone/concrete buildings at the expense of public space which has deteriorated continuously in the city over the last three decades.

\section{References}

[1] Gradus, Y. (1976) Factorial Ecology in a Controlled Urban System: The Case of Metropolitan Haifa, Israel. Geografiska Annaler. Series B, Human Geography, 58, 59-67.

[2] Berry, B.J.I. and Kasarda, J.D. (1977) Contemporary Urban Ecology. Macmillan Publishing Co., New York.

[3] Evans, D.J. (1973) A Comparative Study of Urban Social Structure in South Wales. In: Clark, B.D. and Gleave, M.B., Eds., Social Patterns in Cities, Institute of British Geographers, London, 169-189.

[4] Timms, D.W.G. (1971) The Urban Mosaic. Cambridge University Press, Cambridge.

[5] Johnston, R.J. (1973) Residential Differentiation in Major New Zealand Urban Areas: A Comparative Factorial Ecology. In: Clark, B.D. and Gleave, M.B., Eds., Social Patterns of Cities, Institute of British Geographers, London, 146-159.

[6] Murdie, R.A. (1969) Factorial Ecology of Metropolitan Toronto, 1951-1961. Research Paper No. 116, Department of Geography, University of Chicago, Chicago.

[7] Davis, W.K.D. and Barrow, G. (1974) Factorial Ecology of Three Prairie Cities. Canadian Geographer, 17, 327-351. https://doi.org/10.1111/j.1541-0064.1973.tb00198.x

[8] Al-Ankary, K.M. (1981) A Comparative Factorial Ecology: Kuwait City, Kuwait and Jackonville, Florida. PhD Dissertation, University of Florida, Gainesville.

[9] Rees, P.H. (1971) Factorial Ecology: And Extended Definition, Survey and Critique. Economic Geography, 47, 220-233. https://doi.org/10.2307/143205

[10] Herbert, D. (1972) Urban Geography: A Social Perspective. David and Charles, Newton Abbot.

[11] Timms, D.W.G. (1970) Comparative Factorial Ecology: Some New Zealand Examples. Environment and Planning, 2, 455-467. https://doi.org/10.1068/a020455

[12] Farhan, Y. and Tarazi, A. (1985) Urban Ecology of Jerash. The Arab Journal for the Humanities, 8, 426-449.

[13] Herbert, D. and Johnston, R.J. (1978) Social Areas in Cities. Vol. 1, Spatial Processes 
and Form. John Wiley, New York.

[14] Rees, P.H. (1979) Residential Patterns in American Cities: 1960. Department of Geography, University of Chicago, Chicago.

[15] U.S. Census Bureau. (2000) Census 2000 Special Report: Racial and Ethnic Residential Segregation in the United States: 1980-2000. U.S. Department of Commerce, Washington DC.

[16] Massey, D.S. and Denton, N.A. (1989) Hypersegregation in the U.S. Metropolitan Areas: Black and Hispanic Segregation along Five Dimensions. Demography, 26, 373-391. https://doi.org/10.2307/2061599

[17] Massey, D.S. and Denton, N.A. (1993) The Dimensions of Residential Segregation. Social Forces, 67, 281-315. https://doi.org/10.1093/sf/67.2.281

[18] Fainstein, N.I. (1993) Race, Class and Segregation: Discourse about African Americans. International Journal of Urban and Regional Research, 17, 384-404. https://doi.org/10.1111/j.1468-2427.1993.tb00228.x

[19] Wilkes, R. and Iceland, J. (2004) Hypersegregation in the Twenty-First Century. Demography, 41, 23-36. https://doi.org/10.1353/dem.2004.0009

[20] Kaplan, D.H., Wheeler, J. and Steven, H. (2015) Urban Geography. Wiley, New York.

[21] Kaplan, D.H. and Holloway, S.R. (1998) Segregation in Cities. Association of American Geographers, Washington DC.

[22] Abu-Lughod, J. (1969) Testing the Theory of Social Area Analysis: The Case of Cairo, Egypt. American Sociological Review, 34, 198-212.

https://doi.org/10.2307/2092177

[23] Berry, B.J.I. and Rees, P. (1969) The Factorial Ecology of Calcutta. The American Journal of Sociology, 74, 445-491.

[24] Hossain, H. (1971) Urban Ecology of Calcuta. Oriental Geographer, (1976), January and July, 35-51.

[25] Taylor, P.J. and Parkes, D.N. (1975) A Kantian View of the City: A Factorial-Ecology Experiment in Space and Time. Environment and Planning A, 7, 671-688. https://doi.org/10.1068/a070671

[26] Grove, J.M. (1996) The Relationship between Patterns and Processes of Social Stratification and Vegetation of an Urban-Rural Watershed. PhD Dissertation, Yale University, New Haven.

[27] Grove, J.M. and Burch, W.R. (1997) A Social Ecology Approach and Application of Urban Ecosystem and Landscape Analysis: A Case Study of Baltimore, Maryland. Urban Ecosystem, 1, 259-275. https://doi.org/10.1023/A:1018591931544

[28] Shochat, E., Warren, B., Faeth, S., Mclntyre, N. and Hope, D. (2006) From Patterns to Emerging Processes in Mechanistic Urban Ecology. Trends in Ecology and Evolution, 21, 186-191. https://doi.org/10.1016/j.tree.2005.11.019

[29] Grimms, N., Faeth, S., Golubiewski, N., Redman, C., Wu, J., Bai, X. and Briggs, J. (2008) Global Change and the Ecology of Cities. Science, 319, 756-760. https://doi.org/10.1126/science.1150195

[30] Cilliers, S. and Siebert, S. (2012) Urban Ecology in Cape Town: South African Comparisons and Reflections. Ecology and Society, 17, 33. https://doi.org/10.5751/ES-05146-170333

[31] Mc Phearson, T., Pickett, S., Grimm, N., Niemelä, J., Alberti, M., Elmqvist, T., Weber, C., Hasse, D., Breuste, J. and Qureshi, S. (2016) Advancing Urban Ecology to- 
ward a Science of Cities. BioSience, 66, 198-212.

https://doi.org/10.1093/biosci/biw002

[32] Ministry of Local Government (2017) The Map of Ramallah and Al-Bireh.

[33] Palestinian Central Bureau of Statistics (2009) Final Results of the Census (Population, Buildings and Housing) Ramallah and Al-Bireh Governorate: Ramallah-Palestine.

[34] Gajbhiye, S.M. and Sharma, S.K. (2015) Prioritization of Watersheds through Morphometric Parameters: A PCA Approach. Applied Water Science, 7, 1505-1519.

[35] Odum, M. (2011) Factor Scores, Structure, and Communality Coefficients; A Primer. Texas A\&M University, College Station. https://files.Eric.Ed.gov/fulltext/ED516688.pdf

[36] Rummel, R.J. (1970) Applied Factor Analysis. Northwestern University Press, Evanston.

[37] Harman, H.H. (1966) Modern Factor Analysis. 2nd Edition, University of Chicago Press, Chicago.

[38] Colding, J. and Barthel, S. (2013) The Potential of "Urban Green Commons" in the Resilience Building of Cities. Ecological Economics, 86, 156-166. https://doi.org/10.1016/j.ecolecon.2012.10.016

[39] Wolch, J., Byrne, J. and Newell, J. (2014) Urban Green Space, Public Health, and Environmental Justice: The Challenge of Making Cities' Just Green Enough. Landscape and Urban Planning, 125, 234-244. https://doi.org/10.1016/j.landurbplan.2014.01.017

[40] Bettencourt, L., Lobo, J., Strumsky, D. and West, G. (2010) Urban Scaling and Its Deviations: Revealing the Structure of Wealth, Innovation and Crime across Cities. PLoS ONE, 5, e13541. https://doi.org/10.1371/journal.pone.0013541 